\title{
Contribution to the species composition and taxonomic status of some Rattus inhabiting Southern Vietnam and Sundaland
}

\begin{abstract}
Alexander E. Balakirev \& Viatcheslav V. Rozhnov
ABSTRACT. The sequencing of Cyt $b$ and COI mtDNA genes was used to investigate the species composition of Rattus rats in Southern Vietnam and establish an actual correspondence between revealed mtDNA haplogroups and taxonomical species for the group in the region. Seven specific level phylogroups corresponding to Rattus tanezumi, $R$. norvegicus, $R$. nitidus, $R$. andamanensis, $R$. exulans, $R$. argentiventer and $R$. tiomanicus were discovered, with European $R$. rattus apparently being absent. By comparing original genetic data with other sequences representing different localities in Indochina and the Sundaland regions from GenBank, transsundaic distribution of R. tiomanicus was shown in continental Indochina well beyond the Isthmus of Kra, along with the other species, $R$. argentiventer, overpassing the limit. The adequacy of species attribution and taxonomic names for three Indochinese species $(R$. andamanensis, $R$. argentiventer and $R$. tiomanicus) is discussed based on comparisons of morphological peculiarities and genetic data set for Vietnamese samples. Corrected nomenclature for specific level haplogroups/species of Rattus in Southeast Asia is proposed.
\end{abstract}

KEY WORDS: Rattus, Indochina, Vietnam, species composition, mammals, taxonomy.

AlexanderE.Balakirev [alexbalakirev@mail.ru] and ViatcheslavV.Rozhnov[rozhnov.v@gmail.com],A.N.Severtsov Institute of Ecology and Evolution, Russian Academy of Sciences, Leninskii pr. 33, Moscow, 119071, Russia; Joint Vietnam-Russian Tropical Research and Technological Centre, Nguyen Van Huyen, Nghia Do, Cau Giay, Hanoi, Vietnam.

\section{О видовом составе и таксономическом статусе некоторых форм Rattus, обитающих в Южном Вьетнаме и на Сундской Суше}

\author{
А.Е. Балакирев, В.В. Рожнов
}

\begin{abstract}
РЕЗЮМЕ. Для исследования фактического видового состава и определения таксономического соответствия, обнаруженных в регионе митохондриальных гаплогрупп представителей рода Rattus, обитающих на территории Южного Вьетнама, было проведено секвенирование генов цитохрома $\sigma$ $(\mathrm{Cyt} b)$ и цитохромоксидазы (COI) митохондриальной ДНК. Было выявлено семь филогрупп видового уровня, соответствующих видам Rattus tanezumi, $R$. norvegicus, $R$. nitidus, $R$. andamanensis, $R$. exulans, $R$. argentiventer и $R$. tiomanicus, при этом европейский R.rattus в регионе обнаружен не был. Сравнением оригинальных генетических данных с данными депонированными в GenBank показано транссундаическое распространение $R$. tiomanicus, который обнаружен в континентальном Индокитае (Южный Вьетнам) значительно севернее Перешейка Кра, равно как и $R$. argentiventer, который тоже переходит эту границу. На основании сравнения черт внешнего строения и молекулярных данных по выборке из Вьетнама обсуждается адекватность видового определения и применяемых видовых названий для трёх индокитайских видов $R$. andamanensis, $R$. argentiventer and $R$. tiomanicus. Предложена корректированная номенклатура для обозначения филогрупп видового уровня рода Rattus в Юго-Восточной Азии.
\end{abstract}

КЛЮЧЕВЫЕ СЛОВА: Rattus, Индокитай, Вьетнам, видовой состав, млекопитающие, таксономия.

\section{Introduction}

Species belonging to the genus Rattus are traditionally considered to be a group difficult to identify, especially in Southeast Asia and the Sunda Islands. The difficulty is caused by a similarity in general appearance, external morphology and skull structure between many of the species and their considerable geographical and ecological variability. This difficulty in identifi- cation led to problems with species identification and sometimes gives rise to conflicting views on the identification of taxa in the fauna of the region. The current situation in the taxonomy of the group creates problems for ecologists, medical zoologists and other specialists in zoology and natural conservation.

During the last century, many studies were focused on investigating the biodiversity of the family Muridae in Southeast Asia. However, until recently Vietnam 
remained the least investigated area in the region in this respect. The taxonomy of the family Muridae was revised many times during this period (Ellerman, 1949; Ellerman \& Morrison-Scott, 1966; Musser \& Carleton, 1993, 2005; Nowak, 1999; Pavlinov, 2005) but until now could not be considered as finally established. The same is true for opinions on the correspondence of forms and species and their natural ranges and ecologies.

Different authors have significantly disagreed on the species composition of the fauna of continental Indochina. Van Peenen (1969) indicated seven species within the Rattus genus for the region (norvegicus, exulans, exiguus, rattus, slaideni, nitidus, and argentiventer). Musser (in Corbet \& Hill, 1992), followed by Pavlinov (2005), in his most complete review of the mammals of Southeast Asia, stated the genus Rattus as also comprising seven species but in a different assemblage (norvegicus, exulans, rattus, nitidus, argentiventer, remotus, and osgoodi). Lunde \& Nguyen Truong Son (2001) agreed with Musser's opinion on Rattus composition, with the addition of $R$. tanezumi considered as a separate species. Kuznetsov (2006) argued that the genus Rattus is even more complex and comprised 10 species at total (norvegicus, exulans, losea, rattus, koratensis, nitidus, argentiventer, remotus, osgoodi, and moliculus). If synonyms are taken into consideration, it follows that $R$. exiguous is a synonym of $R$. losea Swinhoe, 1870 and $R$. slideni is a synonym of $R$. tanezumi Temminck, 1844, which is in agreement with Musser \& Carleton (1993) (or the synonym for $R$. koratensis in accordance with Kuznetsov, 2006), generally, it may be proposed the number of Rattus species in Indochina is in the limits from seven to ten.

A series of successful investigations of the genetic diversity in the genus in the Asia Pacific region (Chinen et al., 2005; Robins et al., 2007, 2010; Pages et al., 2010) were performed recently. Using the analysis of short mtDNA fragments (cytochrome $b$ genes and subunit I cytochrome oxidase gene, Cyt $b$ and COI) (Ross et al., 2003; Robins et al., 2007), the possibilities to determine genetic species and estimate their proper taxonomic attributions was clearly demonstrated. A set of discrete specific genetic clades have been shown (Chinen et al., 2005; Robins et al., 2007), and minimal genetic distances to segregate specific levels taxa were estimated (Pages et al., 2010). Currently, ten specific level phylogroups have been characterized for Sundaland area, with more than 20 such groups recognized for entire Australasian region. The phylogenetic relationships among them are discussed in detail by Robins et al. $(2007,2010)$. More than 600 available sequences of Cyt $b$ and COI genes in the mtDNA, the IRBP gene and some other genes of wild (non-laboratorial) representatives of Rattus were deposited in international gene databases (GenBank, NCBI, DDBJ) by December 31,2010 , providing plenty of material for an accurate definition of intrageneric taxonomy based on up-todate molecular approaches to actual natural biodiversity investigations. Nevertheless, the problem of recipro- cal correspondence of the scientific species names for revealed species-level phylogroups with the generally accepted taxa names, initially described exclusively based on general appearance and some morphological traits in skull structure, is yet to be resolved for the general revision of the species composition in the genus.

Thus, in this paper, we endeavored to present some contribution to species composition of the genus Rattus from continental Indochina and Sundaland and estimate specific names usage for genetically delimitated species based on comparison of currently available molecular genetics and morphological data. Authors do not pretend for explicit taxonomic revision for the genus in the region, nevertheless the discussions listed bellow may be useful to shed some light to some important taxonomical questions and contribute to proper taxonomic names usage.

\section{Materials and methods}

\section{Specimens studied}

We analyzed field collections and other material obtained during a series of expeditions performed by the Joint Vietnam-Russian Tropical Research and Technological Centre from 2007 to 2011 in Vietnam. The materials were collected in Hoang Lien Nature Reserve (Lao Cai Province), Nam Cat Tien National Park (Dong Nai Province), Bu Gia Map Nature Reserve (Binh Phuc Province), Con Dao National Park (Ba Ria - Vung Tau Province), precincts of the Lo Go Xa Mat Nature Reserve (Tay Ninh Province), Binh Chau Nature Reserve near Xuyen Moc (Ba Ria - Vung Tau Province), Ngoc Linh Nature Reserve (Kon Tum Province), Gia Lai Province near Pleiku, Dak Lak Province near Ea Wy (Tay Nguyen Plateau) and in the rural areas surrounding Vinh Long, Hanoi, Hai Phong and Ho Chi Minh City. A map of the collection sites are shown in Fig. 1.

Preliminary species identification was based on field guides (Van Peenen, 1969; Lunde \& Nguyen Truong Son, 2001) and on reviews by Corbet \& Hill (1992) and Kuznetsov (2006). Captured rats were photographed, weighed and measured, after which a small piece of liver or muscle tissue was collected (fixed in 96\% ethanol) for molecular investigations. We also collected the skull and skin for comparative morphological investigations, performed visually and using a stereomicroscope MBS-10. For preparing illustrations for the paper some of the skulls were photographed in more considerable details under macro mode by Olympus S350 digital camera (8 Mpx). In general, we examined the morphological materials (skulls, skins and alcoholpreserved carcasses) for more than one hundred animals, most of which (72 individuals) were genotyped. The majority of the morphological materials are deposited at the Zoological Museum of Moscow State University, Moscow, Russia (ZMMU), and some specimens are deposited in the Zoological Institute Russian 


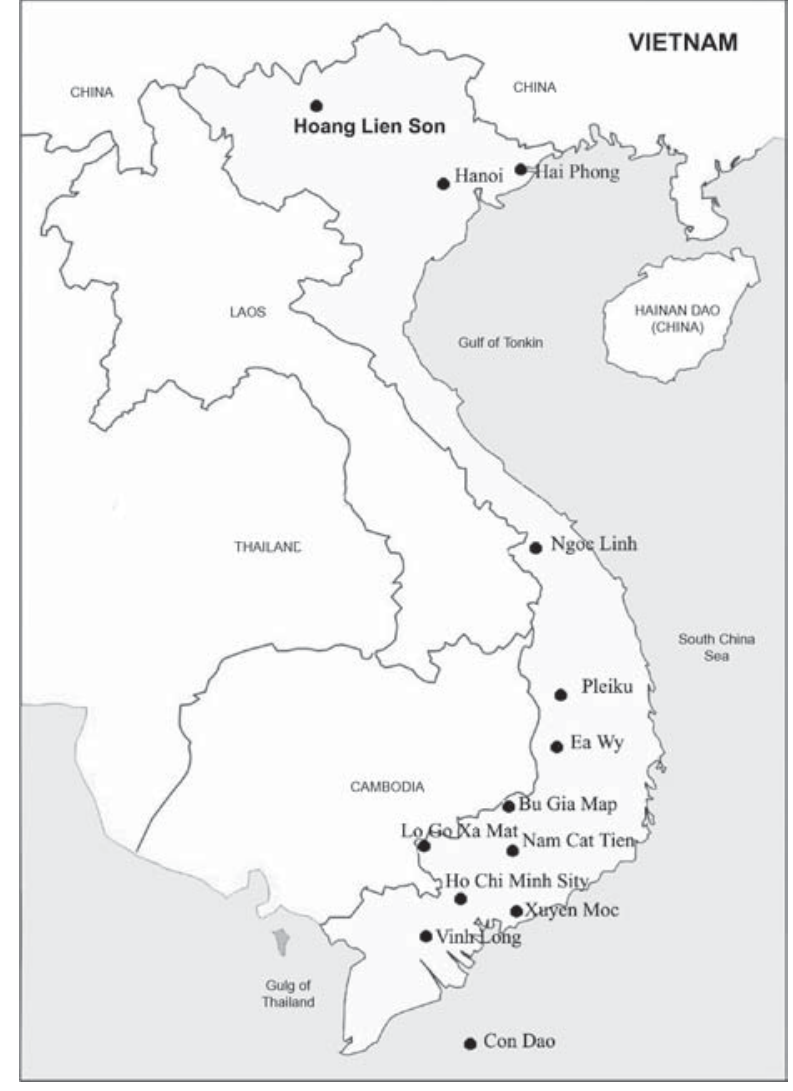

Figure 1. Original sample locations. See Table 1 for detailed information.
Academy of Sciences, Saint-Petersburg, Russia (ZIN), or comprise the personal collections of the authors (Tab. 1).

DNA extraction, amplification and sequencing

Genomic DNA was isolated by the routine phenolchloroform method (Sambrook et al., 1989) and purified by two-fold alcohol precipitation using a DNA Purification Kit (Fermentas). A full-sized cytochrome $b$ (Cyt $b)$ gene (1143 bp) and/or a $680 \mathrm{bp}$ portion of the subunit I cytochrome oxidase gene (COI) was amplified using the universal conservative primers $\mathrm{H} 15915 \mathrm{R}$ (5' GGAATTCATCTCTCCGGTTTACAAGAC 3'), Cyt bRglu2L (5'_CAGCATTTAACTGTGACTAATGAC 3'), and CytbRCb9H (5' TACACCTAGGAGGTCTTTAATTG $3^{\prime}$ ) for the $\overline{\mathrm{C} y t} b$ gene and BatL 5310 (5' CCTACTCRGCCATTTTACCTATG_3') and R6036R (5', ACTTCTGGGTGTCCAAAGAĀTCA 3') for the COI gene (Kocher et al., 1989; Irwin et al., 1991; Robins et al., 2007). The polymerase chain reaction was conducted in 30 to $50 \mu \mathrm{l}$ of $\mathrm{KCl}$ containing PCR buffer (Fermentas). The PCR mixture contained $50 \mathrm{mM}$ of each dNTP, $2 \mathrm{mM}$ of $\mathrm{MgCl}_{2}, 10$ to $12 \mathrm{pmol}$ of each primer, $1 \mathrm{U}$ Taq DNA polymerase (Fermentas) and 20 to $50 \mathrm{ng}$ of DNA template. Amplification was conducted according to the following protocol: denaturation $40 \mathrm{~s}$ at $95^{\circ}, 40$ cycles $30 \mathrm{~s}$ long at $95^{\circ}, 1 \mathrm{~min}$ at $48-56^{\circ}, 40 \mathrm{~s}$ at $72^{\circ}$, and terminating elongation for 2 min at $72^{\circ}$. PCR products were purified using a DNA Purification Kit (Fermentas) following the manufactur-

Table 1. List of original samples.

\begin{tabular}{|c|c|c|c|c|c|c|c|c|}
\hline \multirow{2}{*}{ No. } & \multicolumn{5}{|c|}{ Samples information } & \multicolumn{2}{|c|}{ Accession numbers } & \multirow{2}{*}{$\begin{array}{c}\text { Museum } \\
\text { number }\end{array}$} \\
\hline & $\begin{array}{c}\text { Specimen } \\
\text { nomination }\end{array}$ & $\begin{array}{l}\text { Taxonomic } \\
\text { nomination }\end{array}$ & Locality & $\begin{array}{l}\text { Voucher } \\
\text { location }\end{array}$ & $\mathrm{HG}$ & Cyt $b$ & COI & \\
\hline 1 & Th7 & R. tanezumi & \multirow{7}{*}{ Ho Chi Minh City } & ZMMU & $\mathrm{R} 2$ & FR775845 & & S-184839 \\
\hline 2 & Th9 & R. tanezumi & & ZMMU & $\mathrm{R} 2$ & FR775846 & & S-184842 \\
\hline 3 & Th10 & R. tanezumi & & ZMMU & $\mathrm{R} 2$ & FR775847 & & S-184843 \\
\hline 4 & Th11 & R. tanezumi & & ZMMU & $\mathrm{R} 2$ & FR775848 & & S-184844 \\
\hline 5 & Th12 & R. tanezumi & & ZMMU & $\mathrm{R} 2$ & FR775849 & & S-184841 \\
\hline 6 & Th14 & R. tanezumi & & ZMMU & $\mathrm{R} 2$ & FR775850 & & S-184846 \\
\hline 7 & Th15 & R. tanezumi & & ZMMU & R2 & FR775851 & & S-188901 \\
\hline 8 & Sh56 & R. tanezumi & \multirow{2}{*}{ Hoang Lien Son } & auth.coll. & $\mathrm{R} 2$ & FR775852 & FR775804 & \\
\hline 9 & SVK10-03 & R. tanezumi & & ZMMU & $\mathrm{R} 2$ & & FR775805 & S-188903 \\
\hline 10 & Sh89 & R. tanezumi & Hanoi & ZMMU & R2 & & FR775806 & S-184840 \\
\hline 11 & $\mathrm{CD} 1$ & R. tanezumi & Con Dao Isl. & auth.coll. & $\mathrm{R} 2$ & & FR775807 & S-188105 \\
\hline 12 & HG2 & R. tanezumi & \multirow{3}{*}{ Hai Phong } & ZMMU & $\mathrm{R} 2$ & HQ907884 & HQ907882 & S-184740 \\
\hline 13 & HG7 & R. tanezumi & & ZMMU & $\mathrm{R} 2$ & HQ907885 & & S-184741 \\
\hline 14 & HG8 & R. tanezumi & & ZMMU & R2 & HQ907886 & HQ907883 & S-184742 \\
\hline
\end{tabular}


Table 1 (continued).

\begin{tabular}{|c|c|c|c|c|c|c|c|c|}
\hline \multirow[b]{2}{*}{ No. } & \multicolumn{5}{|c|}{ Samples information } & \multicolumn{2}{|c|}{ Accession numbers } & \multirow{2}{*}{$\begin{array}{l}\text { Museum } \\
\text { number }\end{array}$} \\
\hline & $\begin{array}{c}\text { Specimen } \\
\text { nomination }\end{array}$ & $\begin{array}{l}\text { Taxonomic } \\
\text { nomination }\end{array}$ & Locality & $\begin{array}{l}\text { Voucher } \\
\text { location }\end{array}$ & HG & Cyt $b$ & $\mathrm{COI}$ & \\
\hline 15 & K17 & R. tiomanicus & \multirow{5}{*}{ Nam Cat Tien } & auth.coll. & $\mathrm{R} 3$ & & FR775822 & S-188904 \\
\hline 16 & K21 & R. tiomanicus & & auth.coll. & R3 & FR775853 & FR775808 & \\
\hline 17 & K67 & R. tiomanicus & & ZMMU & R3 & FR775854 & FR775809 & S-186948 \\
\hline 18 & K89 & R. tiomanicus & & ZMMU & $\mathrm{R} 3$ & FR775855 & & S-184848 \\
\hline 19 & F27 & R. tiomanicus & & auth.coll. & R3 & & FR775810 & \\
\hline 20 & $91165 \mathrm{nc}$ & R. tiomanicus & Ngoc Linh & ZIN & $\mathrm{R} 3$ & & FR775811 & 91165 \\
\hline 21 & Th16 & R. tiomanicus & HCM City & ZMMU & R3 & FR775856 & & S-184849 \\
\hline 22 & SM1 & R. tiomanicus & Xuyen Moc & ZMMU & R3 & FR775857 & & S-188905 \\
\hline 23 & Z22 & R. tiomanicus & \multirow{2}{*}{ Pleiku } & auth.coll. & $\mathrm{R} 3$ & FR775858 & & \\
\hline 24 & Z37 & R. tiomanicus & & auth.coll. & R3 & FR775859 & & \\
\hline 25 & Lo25 & R. tiomanicus & \multirow{2}{*}{ Lo Go Xa Mat } & ZMMU & R3 & FR775860 & & S-188908 \\
\hline 26 & Lo37 & R. tiomanicus & & ZMMU & R3 & FR775861 & & S-188909 \\
\hline 27 & VL1 & R. tiomanicus & \multirow{9}{*}{ Vinh Long } & ZMMU & R3 & & FR775812 & S-188910 \\
\hline 28 & VL5 & R. tiomanicus & & ZMMU & R3 & FR775862 & FR775813 & S-188911 \\
\hline 29 & VL6 & R. tiomanicus & & ZMMU & R3 & & FR775814 & S-188912 \\
\hline 30 & VL7 & R. tiomanicus & & ZMMU & R3 & FR775863 & FR775815 & S-188913 \\
\hline 31 & VL8 & R. tiomanicus & & ZMMU & $\mathrm{R} 3$ & FR775864 & FR775816 & S-188914 \\
\hline 32 & VL9 & R. tiomanicus & & ZMMU & R3 & & FR775817 & S-188915 \\
\hline 33 & VL10 & R. tiomanicus & & ZMMU & R3 & & FR775818 & S-188916 \\
\hline 34 & VL26 & R. tiomanicus & & ZMMU & R3 & FR775865 & FR775819 & S-188917 \\
\hline 35 & VL42 & R. tiomanicus & & auth.coll. & R3 & & FR775820 & \\
\hline 36 & $\mathrm{CD} 37 \mathrm{c}$ & R. tiomanicus & Con Dao Isl. & ZMMU & R3 & & FR775821 & S-188918 \\
\hline 37 & R1 & R. andamanensis & \multirow{4}{*}{ Nam Cat Tien } & auth.coll. & R7 & FR775866 & & \\
\hline 38 & R3 & R. andamanensis & & auth.coll. & R7 & FR775867 & & \\
\hline 39 & K79 & R. andamanensis & & ZMMU & R7 & FR775868 & & S-188919 \\
\hline 40 & K90 & R. andamanensis & & ZMMU & R7 & FR775869 & & S-184833 \\
\hline 41 & BZM1 & R. andamanensis & \multirow{5}{*}{ Bu Gia Map } & ZMMU & R7 & FR775870 & & S-188920 \\
\hline 42 & BZM3 & R. andamanensis & & ZMMU & R7 & FR775871 & & S-188921 \\
\hline 43 & BZM4 & R. andamanensis & & auth.coll. & R7 & FR775872 & & \\
\hline 44 & BZM7 & R. andamanensis & & ZMMU & R7 & FR775873 & & S-188922 \\
\hline 45 & BZM8 & R. andamanensis & & ZMMU & R7 & FR775874 & & S-184832 \\
\hline 46 & VL22 & R. argentiventer & \multirow{8}{*}{ Vinh Long } & ZMMU & R6 & & FR775823 & S-188923 \\
\hline 47 & VL23 & R. argentiventer & & ZMMU & R6 & & FR775824 & S-188924 \\
\hline 48 & VL25 & R. argentiventer & & ZMMU & R6 & FR775875 & FR775825 & S-188925 \\
\hline 49 & VL27 & R. argentiventer & & ZMMU & R6 & FR775876 & FR775826 & S-188926 \\
\hline 50 & VL28 & R. argentiventer & & ZMMU & R6 & & FR775827 & S-188927 \\
\hline 51 & VL29 & R. argentiventer & & auth.coll. & R6 & & FR775828 & \\
\hline 52 & VL31 & R. argentiventer & & ZMMU & R6 & & FR775829 & S-188928 \\
\hline 53 & VL33 & $R$. argentiventer & & ZMMU & R6 & FR775877 & FR775830 & S-188929 \\
\hline
\end{tabular}


Table 1 (continued).

\begin{tabular}{|c|c|c|c|c|c|c|c|c|}
\hline \multirow[b]{2}{*}{ No. } & \multicolumn{5}{|c|}{ Samples information } & \multicolumn{2}{|c|}{ Accession numbers } & \multirow{2}{*}{$\begin{array}{l}\text { Museum } \\
\text { number }\end{array}$} \\
\hline & $\begin{array}{l}\text { Specimen } \\
\text { nomination }\end{array}$ & $\begin{array}{l}\text { Taxonomic } \\
\text { nomination }\end{array}$ & Locality & $\begin{array}{l}\text { Voucher } \\
\text { location }\end{array}$ & $\mathrm{HG}$ & Cyt $b$ & $\mathrm{COI}$ & \\
\hline 54 & VL34 & R. argentiventer & \multirow{5}{*}{ Vinh Long } & ZMMU & R6 & FR775878 & FR775831 & S-188930 \\
\hline 55 & VL35 & R. argentiventer & & ZMMU & R6 & FR775879 & FR775832 & S-188931 \\
\hline 56 & VL36 & R. argentiventer & & ZMMU & R6 & FR775880 & FR775833 & S-188932 \\
\hline 57 & VL39 & R. argentiventer & & auth.coll. & R6 & FR775881 & FR775834 & \\
\hline 58 & VL41 & R. argentiventer & & auth.coll. & R6 & FR775882 & FR775835 & \\
\hline 59 & D29 & R. nitidus & Ea Wy & ZMMU & $\mathrm{R} 10$ & FR775883 & & S-188933 \\
\hline 60 & $\mathrm{Z} 40$ & R. nitidus & Pleiku & ZMMU & $\mathrm{R} 10$ & FR775884 & & S-188934 \\
\hline 61 & VL3 & R. exulans & \multirow{8}{*}{ Vinh Long } & ZMMU & $\mathrm{R} 8$ & & FR775836 & S-188935 \\
\hline 62 & VL4 & R. exulans & & ZMMU & $\mathrm{R} 8$ & & FR775837 & S-188936 \\
\hline 63 & VL12 & R. exulans & & ZMMU & $\mathrm{R} 8$ & & FR775838 & S-188937 \\
\hline 64 & VL13 & R. exulans & & auth.coll. & $\mathrm{R} 8$ & & FR775839 & \\
\hline 65 & VL14 & R. exulans & & auth.coll. & $\mathrm{R} 8$ & & FR775840 & \\
\hline 66 & VL15 & R. exulans & & auth.coll. & $\mathrm{R} 8$ & & FR775841 & \\
\hline 67 & VL40 & R. exulans & & auth.coll. & $\mathrm{R} 8$ & FR775885 & FR775842 & \\
\hline 68 & VL43 & R. exulans & & auth.coll. & $\mathrm{R} 8$ & FR775886 & FR775843 & \\
\hline 69 & Th1 & R. norvegicus & \multirow{4}{*}{ Ho Chi Minh City } & auth.coll. & R9 & FR775887 & & \\
\hline 70 & Th3 & R. norvegicus & & ZMMU & R9 & FR775888 & & S-184835 \\
\hline 71 & Th4 & R. norvegicus & & ZMMU & R9 & FR775889 & & S-184836 \\
\hline 72 & Th8 & R. norvegicus & & ZMMU & R9 & FR775890 & & S-188938 \\
\hline 73 & K76 & B. indica & Nam Cat Tien & ZMMU & & FR775891 & & S-188939 \\
\hline 74 & VL24 & B. indica & Vinh Long & ZMMU & & & FR775844 & S-188940 \\
\hline
\end{tabular}

er's protocol and sequenced by Applied Biosystems 3130 Genetic Analyzer using an ABI PRISM BigDye Terminator Cycle Sequencing Ready Reaction Kit for both nucleotide chains, using the same primers as for the initial PCR.

All Cyt $b$ and COI gene sequences that were obtained and used for comparative analysis of genetic distances and phylogenetic groups delimitation were deposited into EMBL databank (FR775804-FR775891, Tab. 1). A number of gene sequences and species used as comparative material were cited by Suzuki et al. (2000, 2003; AB033701-AB033702, AB096841), Chinen et al. (2005; AB211039-AB211053), Schlick et al. (2006; DQ 673907-DQ673914), Robins et al. (2007; EF186409EF186512, EF186524-EF186528, F186559-EF186561, EF186605-EF186627), Truong et al. (2009; AB355899AB355901), Pages et al. (2010; HM217362-HM 217596), Tollenaere et al. (2010; GQ891569-GQ 891608), and Bastos et al. (2011; DQ439816-DQ 439864). Totally, we studied 227 specimens with geographic locations for the Cyt $b$ gene and 178 specimens for COI, including original $49 \mathrm{Cyt} b$ and 43 COI sequences from 72 individuals of Rattus from Vietnam.
We also used one specimen of M. musculus (J01420) as a distant out-group and two specimens of Bandicota indica from Vietnam as neighboring out-groups (Tab. 1).

Sequences alignment and phylogenetic analysis

Sequence alignment was carried out using the software program BioEdit (Hall, 1999). The phylogenetic trees were constructed using minimum evolution (ME) and neighbor-joining (NJ) methods. Genetic distances were calculated by the Tamura 3-parameter model (T3P) for all types of substitutions (Ts+Tr) using MEGA 3.1 software (Kumar et al., 2004). The bootstrap support level for nodes was calculated by 1000 replications. Final correspondence between specific level haplogroups/species and any morphologically delimitated species was performed in agreement with the genetic species concept (Bradley \& Baker, 2001; Baker \& Bradley, 2006; Pages et al., 2010). All COI gene sequences are also included in our collaborative project named Indochinese Muridae (ICMBA) at Barcoding of 


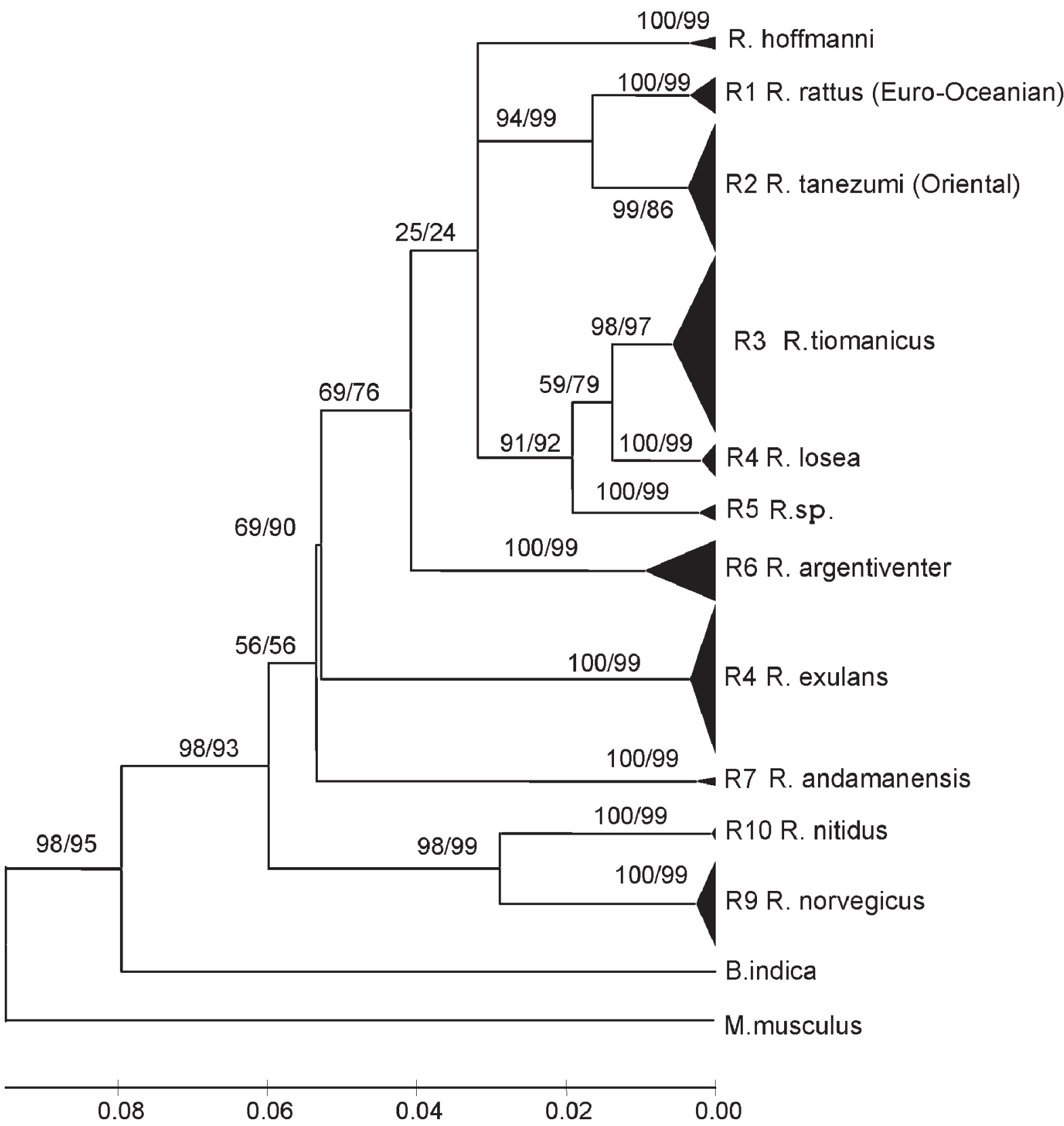

Figure 2. Phylogenetic relationships within Rattus species inhabiting the Sunda Shelf region; ME tree. Distal branches are shown compressed. Species nomination generally follows Robins et al. (2007) but see discussion below. Bootstrap values for the Cyt $b / C O I$ genes are shown above branches. Intergroup divergence scale is at the bottom.

Life System, BOLD (Savolainen et al., 2005; www. barcodinglife.com) and have been used for interspecific comparisons within the BOLD system.

\section{Results}

\section{Genetic phylogroup compositions}

Nine specific level haplogroups of the Rattus spp. can be recognized among the data set from Sundaland, with seven inhabiting Vietnam (Fig. 2). Five of them are closely related species of the Rattus group, with hardly resolved interrelations within this subcluster. Between group means genetic distances, $\left(\mathrm{d}_{\mathrm{bo}}\right)$ for Cyt $b$ is $0.038-0.055$; for COI is $0.028-0.069$ ). The topologies of the trees that were constructed based on Cyt $b$ and COI sequences using both the NJ and ME methods were almost identical, with only negligible differences in bootstrap values for some of the distal clades. Thus, we present only a generalized tree, shown in Figure 2. Intra- and intergroup genetic distances $\left(\mathrm{d}_{\mathrm{bg}}, \mathrm{d}_{\mathrm{wg}}\right.$, Tajima 3-parameter, T3P) are shown in Table 2. 
Table 2. Mean genetic distances among Rattus spp. from the Sunda Shelf region.

\begin{tabular}{|c|c|c|c|c|c|c|c|c|c|c|c|c|}
\hline Species & $n$ & & & & & & & & & & & \\
\hline \multirow{2}{*}{$\mathrm{R} 1$, R. rattus } & 30 & 0.005 & 0.005 & 0.007 & 0.007 & 0.006 & 0.010 & 0.010 & 0.008 & 0.011 & 0.011 & 0.011 \\
\hline & 9 & 0.004 & 0.007 & 0.012 & 0.011 & 0.011 & 0.011 & 0.012 & 0.015 & 0.016 & 0.016 & 0.019 \\
\hline \multirow{2}{*}{$\mathrm{R} 2$, R. tanezumi } & 61 & 0.041 & 0.009 & 0.007 & 0.008 & 0.007 & 0.010 & 0.010 & 0.009 & 0.012 & 0.013 & 0.012 \\
\hline & 29 & 0.033 & 0.005 & 0.010 & 0.009 & 0.010 & 0.011 & 0.011 & 0.014 & 0.015 & 0.015 & 0.018 \\
\hline \multirow{2}{*}{$\mathrm{R} 3$, R. tiomanicus $*$} & 41 & 0.057 & 0.065 & 0.011 & 0.006 & 0.006 & 0.009 & 0.010 & 0.009 & 0.011 & 0.011 & 0.011 \\
\hline & 44 & 0.075 & 0.062 & 0.005 & 0.007 & 0.008 & 0.010 & 0.011 & 0.013 & 0.014 & 0.015 & 0.018 \\
\hline \multirow{2}{*}{$\mathrm{R} 4$, R. losea } & 8 & 0.062 & 0.068 & 0.038 & 0.003 & 0.006 & 0.009 & 0.010 & 0.009 & 0.011 & 0.010 & 0.011 \\
\hline & 8 & 0.067 & 0.057 & 0.028 & 0.002 & 0.008 & 0.010 & 0.012 & 0.013 & 0.015 & 0.016 & 0.018 \\
\hline \multirow{2}{*}{$\mathrm{R} 5, R$. sp. $*$} & 4 & 0.040 & 0.053 & 0.041 & 0.041 & 0.005 & 0.008 & 0.010 & 0.010 & 0.012 & 0.012 & 0.011 \\
\hline & 5 & 0.069 & 0.062 & 0.039 & 0.037 & 0.003 & 0.009 & 0.012 & 0.014 & 0.014 & 0.015 & 0.017 \\
\hline \multirow{2}{*}{ R. hoffmanni } & 3 & 0.074 & 0.080 & 0.066 & 0.059 & 0.055 & 0.004 & 0.011 & 0.012 & 0.013 & 0.013 & 0.012 \\
\hline & 3 & 0.068 & 0.067 & 0.064 & 0.060 & 0.058 & 0.005 & 0.012 & 0.014 & 0.015 & 0.014 & 0.017 \\
\hline \multirow{2}{*}{$\mathrm{R} 6, R$. argentiventer } & 11 & 0.096 & 0.101 & 0.101 & 0.095 & 0.085 & 0.078 & 0.008 & 0.010 & 0.012 & 0.013 & 0.012 \\
\hline & 15 & 0.089 & 0.081 & 0.080 & 0.082 & 0.084 & 0.083 & 0.014 & 0.014 & 0.015 & 0.015 & 0.018 \\
\hline \multirow{2}{*}{$\mathrm{R} 7, R$ andamanensi } & 11 & 0.078 & 0.089 & 0.088 & 0.088 & 0.079 & 0.092 & 0.101 & 0.012 & 0.011 & 0.012 & 0.012 \\
\hline & 2 & 0.109 & 0.102 & 0.097 & 0.090 & 0.095 & 0.096 & 0.110 & 0.005 & 0.017 & 0.016 & 0.018 \\
\hline \multirow{2}{*}{$\mathrm{R} 8, R$. exulans } & 37 & 0.101 & 0.109 & 0.097 & 0.100 & 0.093 & 0.103 & 0.115 & 0.098 & 0.005 & 0.014 & 0.013 \\
\hline & 36 & 0.121 & 0.110 & 0.096 & 0.098 & 0.101 & 0.108 & 0.121 & 0.128 & 0.003 & 0.016 & 0.016 \\
\hline \multirow{2}{*}{$\mathrm{R} 9, R$. norvegicus } & 16 & 0.120 & 0.132 & 0.113 & 0.112 & 0.101 & 0.111 & 0.133 & 0.130 & 0.137 & 0.004 & 0.008 \\
\hline & 21 & 0.119 & 0.114 & 0.111 & 0.123 & 0.113 & 0.110 & 0.124 & 0.119 & 0.128 & 0.003 & 0.010 \\
\hline \multirow{2}{*}{$\mathrm{R} 10, R$. nitidus } & 5 & 0.132 & 0.139 & 0.125 & 0.127 & 0.105 & 0.105 & 0.143 & 0.127 & 0.135 & 0.060 & 0.007 \\
\hline & 3 & 0.144 & 0.127 & 0.128 & 0.136 & 0.123 & 0.130 & 0.144 & 0.134 & 0.121 & 0.058 & 0.001 \\
\hline
\end{tabular}

Note: The distances calculated based on the Cyt $b$ gene are in the upper lineage, and the distances calculated based on the COI gene are in the lower lineage. Between-group means $\left(\mathrm{d}_{\mathrm{bg}}\right)$ are in the bottom left, and standard errors (S.E.) are in the top right, within group means $\left(\mathrm{d}_{\mathrm{wg}}\right)$ in the diagonal.

* See discussion about probable proper taxonomic name for this species in the text.

For full integrity of background and to cover all currently characterized genetic species of the Rattus group in the Asia-Pacific region, we also brought the sequences treated as $R$. tiomanicus Miller, 1900 (R5) and $R$. hoffmanni Matschie, 1901 by Robins et al. $(2007,2010)$ to our study, which rise the number of species studied to 11. Haplogroups nominations (R1R10) follow Pages et al. (2010). Because the majority of our material represented Southern Vietnam, $R$. losea (R4), the species typical in central and northern Indochina, is lacking in our samples. Only few information is currently available on the general features of the species including its actual geographic ranges and taxonomical limits. Even so, there are not any doubts that this species is present in the fauna of the country. Another species, which morphologically close to $R$. losea, R. osgoodi Musser et Newcomb, 1985 (Musser \& Newcomb, 1985), describing from Langbian Peak in Dalat Plateau, is still not characterized genetically. This species is apparently present in the fauna of Vietnam, but there are no doubts about the point that any of the genetic lineages examined in the paper actually represent $R$. osgoodi. Thus, formal diversity in the genus Rattus is shown to be within the previously established limits (Musser \& Carleton, 2005), but to obtain a better estimation of taxonomic composition, an analysis of correspondence of genetic lineages to morphological species is needed.

\section{Discussion}

Analysis of phylogroups geographical distributions

Using an analysis of capture site locations and phylogenetic relationships between genetic groups, the conclusion can be drawn which may not completely 


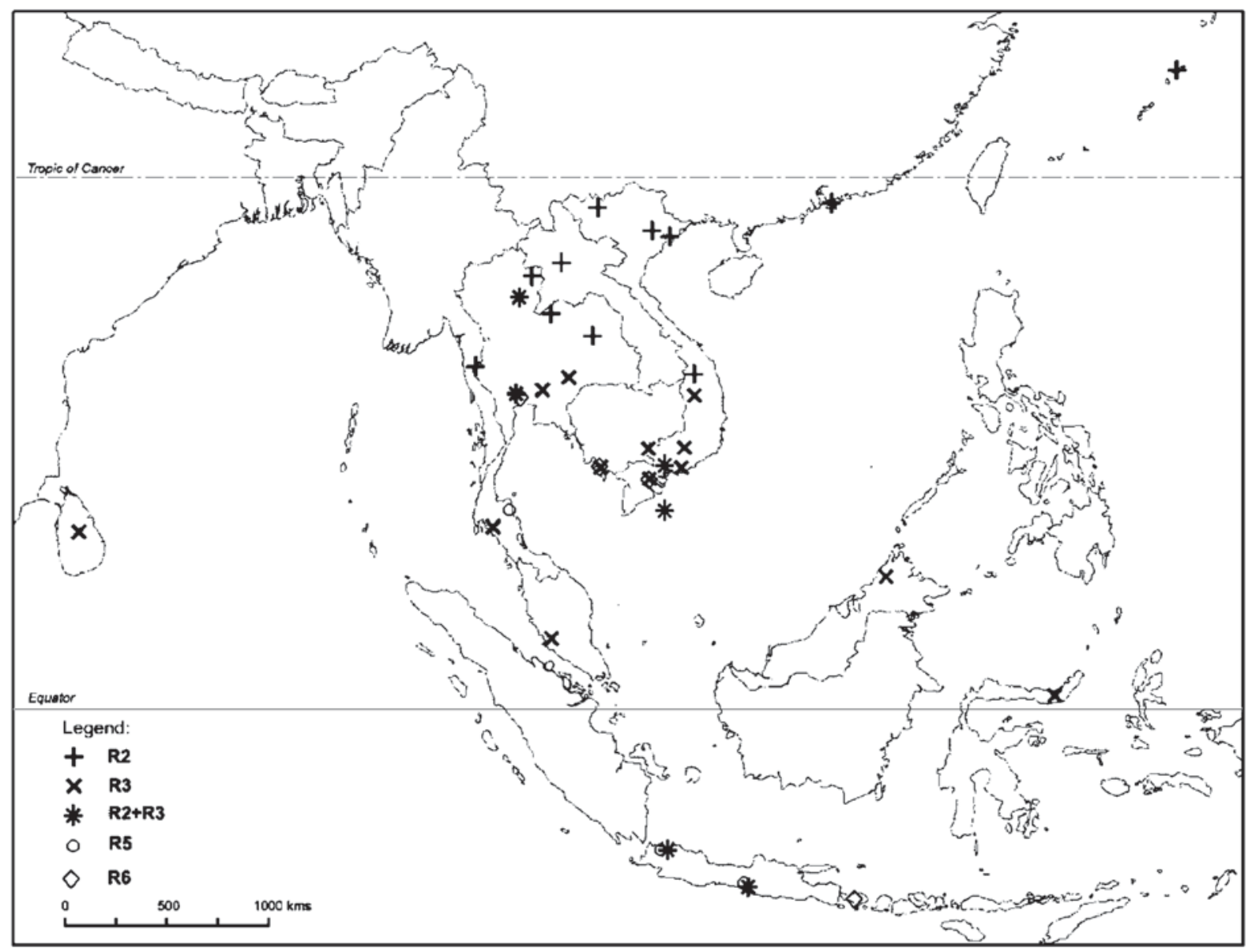

Figure 3. Distribution of some specific level haplogroups/species of the genus Rattus in the Sunda Shelf region. Haplogroup nominations follow Pages et al. (2010). Site localities for R3 in Kalimantan and R6 in Java presented by morphological data.

agree with the generally accepted taxonomic concept of the genus Rattus (Musser \& Carleton, 2005; Pavlinov, 2005). Under this conception, $R$. argentiventer Robinson and Kloss, 1916 and $R$. tiomanicus are restricted in its northern range by Isthmus of Kra. It can be seen in Figure 3 that no less than three genetic groups (R3, R5, R6), probably corresponding to $R$. tiomanicus, $R$. argentiventer and one other unclearly nominated species, represent a wide distribution both to the north and to the south from the most significant zoogeographic limit in the region, the Isthmus of Kra. Thus, it may be stated that there is genetic uniformity within the whole series of continental and Sundaic species instead of insulation and specific segregation of forms in the area of the Sunda Shelf, as suggested earlier.

Based on available genetic data, it is evident that the most common species in continental Indochina (Thailand, Cambodia, and Vietnam), generally referred to as $R$. rattus Linnaeus, 1758 or $R$. tanezumi, in fact could not be regarded as either of these species. This species treated as $R$. diardi in Robins et al. (2007) and Pages et al. (2010). However, the specific name diardi is currently excluded from a list of valid synonyms for any of the generally accepted Rattus species (Musser \& Carleton, 2005). Moreover, there have been no reports of diardi spreading to the north beyond the Isthmus of Kra, though this semisynanthropic rattus-group species widely distributed on the Malay Peninsula, on some islands of the Sunda Archipelago (Java, Sulawesi) and well beyond the region right up to Sri Lanka. In Southern Vietnam, the rats preferably inhabit vegetable gardens, rice fields, grasslands and shrubs near human settlements; sometimes, though rarely, they can be caught within human houses.

It have not been noticed previously on the range of R. tiomanicus (R5, follows Robins et al., 2007, Pages et al., 2010) spreading northward from the previously described zoogeographical limit, which, as has been shown by above mentioned authors, spreads well to the north on peninsular Thailand and Cambodia. However, we failed to record this haplogroup in Vietnam. The genetic lineage R6, which appears to be $R$. argentiventer, is also shown to be distributed well beyond the Isthmus of Kra and has been recorded both in Southern Cambodia (Pages et al., 2010) and in the Mekong delta (our data). 
When we combined all of the material for the rattus group available in GenBank (more than 300 specimens) with our original data from Vietnam, we failed to find any individuals belonging to haplogroup R1, considered as $R$. rattus in the Indochina and Sundaland areas. This species is recorded in the region only from New Zealand, Polynesia and Japan. It is should be mentioned that $R$. rattus and $R$. tanezumi could hybridize and produce fertile hybrids (Chinen et al., 2005), but any genetic traces of $R$. rattus are still absent in the region. In spite of the fact the absence cannot be logically approved, it is obvious that if the European black rat $R$. rattus actually forms any stable populations anywhere in Indochina (most likely in ports, airports or in warehouses and trans-shipment points), their distribution here actually represents sporadic foci or enclaves, expansions from which are apparently hampered by competition with indigenous species, mainly $R$. tanezumi, $R$. losea and $R$. argentiventer. Detailed investigation of such types of habitats was beyond of the scope of our study, so we failed to find any of such enclaves. However, to avoid confusion, it is recommended to be very prudent when using the specific name $R$. rattus anywhere in Indochina.

Therefore, based on available data, we can conclude the lack of true $R$. rattus from the fauna of Indochina and the wide distributions of many species considered to be endemic to the Sundaic and Malayan zoogeographical subregions. If the former phenomenon can be explained naturally, the latter may have arisen from misidentification of original samples and erroneous taxonomic name usage. Regardless, based on the obvious genetic uniformity of whole series of forms in the regions both to the north and south from the Isthmus of Kra, questions arise regarding the taxonomic status of these forms and the validity of their scientific names. Unfortunately, earlier authors (Robins et al., 2007; Pages et al., 2010) were guided only by the authors' identifications of the museum samples from a label and by a principle of locality to decide on the appropriate taxonomic names for revealed genetic clades; the morphological characters of specific museum specimens were not examined. We acknowledge the utility and higher resolution of comprehensive genetic approach for the purposes of species diagnosis, but it is necessary to emphasize that for such complex group as the genus Rattus in the Asia Pacific region, it is essential to compare any genetic data with the original morphological and museum material to determine the correct taxonomic names for the samples.

\section{Contribution on taxonomical status and no-} menclature for recorded genetic lineages

We attempted to makes clearer what exactly taxonomic names may be correct or, at least, as most as appropriate to attribute to genetic lineages/species discovered using not only genetic but also morphological data (skins, skulls, carcasses and photo images along with a personal observations from live animals) for our Vietnamese specimens, many of which proved to be genetically identical to many of the forms discussed in Robins et al. (2007, 2010) and Pages et al. (2010) (R2, R3, R6, R7, R8, R9, and R10). Comparison of the general appearance and distinctive morphological features of the skull for revealed specific level phylogroups, allowing us to assume its association with some forms and species which have been described early only morphologically.

From seven Vietnamese genetic lineages mentioned above, the attribution for four haplogroups, namely R2 (R. tanezumi), R8 ( $R$. exulans Peale, 1848), R9 ( $R$. norvegicus Berkenhout, 1769), and R10 (R. nitidus Hodgson, 1845), was not difficult to determine based on their obvious morphological peculiarities. Likewise, the attribution of haplogroups $\mathrm{R} 1$ (R. rattus) and $\mathrm{R} 2(R$. tanezumi) was recently performed by Chinen et al. (2005) based on karyologically confirmed specimens representing both of the species captured in several sites in Japan, including one place in close vicinity to the possible terra typica for $R$. tanezumi, near Nagasaki, Kyushu Island (see Jones \& Johnson, 1965). Three other species also bear may be not so prominent, but clear enough morphological appearances and their specific diagnosis can be made based on comparative analysis of general and skull morphology. All of them were recorded in fauna of Vietnam; they also demonstrate well-separated, distinct clades on a phylogenetic tree. Nevertheless, there has been long term discussion regarding the identities of other species, $R$. argentiventer, $R$. andamanensis Blyth, 1860 (syn. R. sikkimensis/R. koratensis/R. remotus), $R$. diardi and $R$. tiomanicus and on the possibility of their correspondences to any of the genetic lineages R3, R5, R6, and R7. It should be noted that, in general case, there is not any strong needs to perform any profound and spectacular statistical analysis to distinguish some peculiar traits which characteristic for the species at their skull structure. Fig. 4 shows photos of the skulls for representatives of the genetic lineages R2, R3, R6 and R7. To compare, we also present reproductions of the skulls (including some types) of different forms and species of genus Rattus from Indochina and the Sunda Archipelago from reviews of Musser (Musser \& Califia, 1982; Musser \& Newcomb, 1985; Musser, 1986). Images of the skull for some Rattus species are also available on the Internet site of the Field Museum of Natural History, Chicago, USA (http://www.fieldmuseum.org).

It is the most simple to establish an attribution of group R6 to species $R$. argentiventer using peculiarities of its general appearance (rust-colored back and entire upper part of body, short ears, dull ochreous spot in front of the ear, light gray, silver-colored belly, dark hind feet; short, broad and lyre-shaped narrowing ahead of the rostrum and very broad and spectacularly formed incisive foramina stretching to the fore edge of the first molars, Fig. 4A, H). These rats inhabiting rice fields in the Mekong delta undoubtedly belong to $R$. argentiven- 

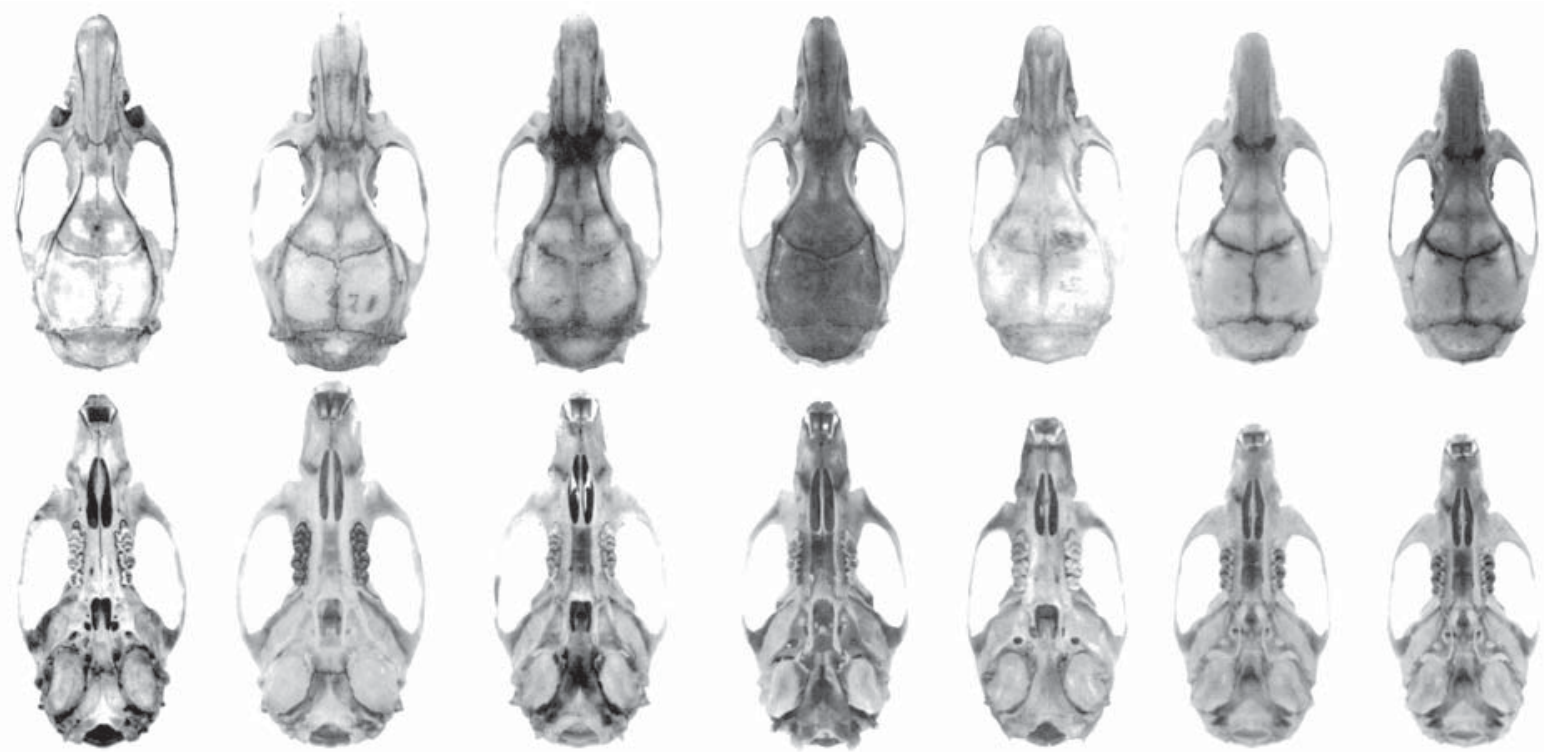

A

B

C

D

E

F

G
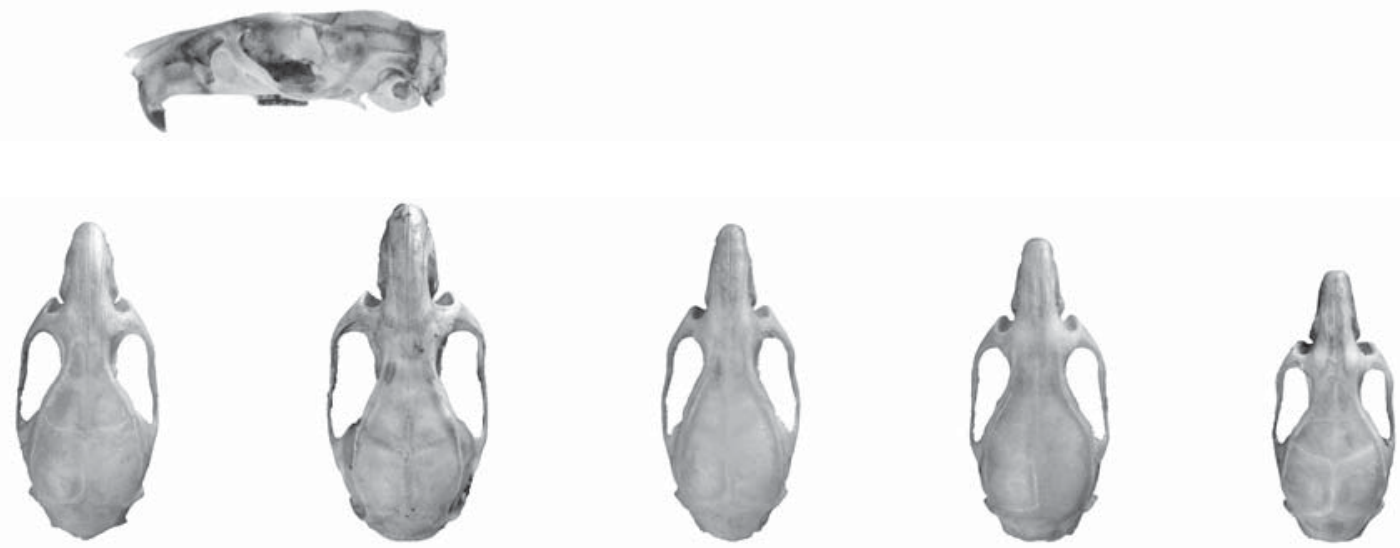

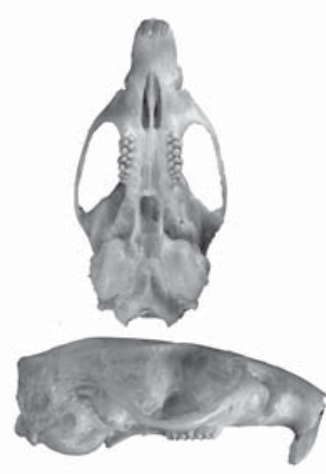

H

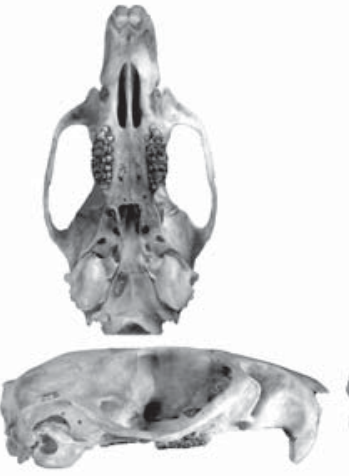

I

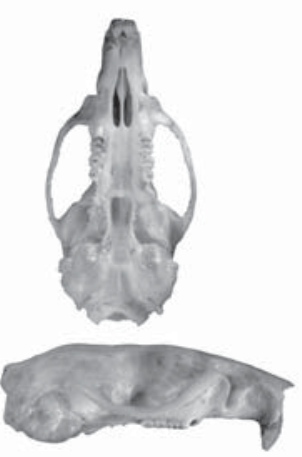

$\mathbf{J}$

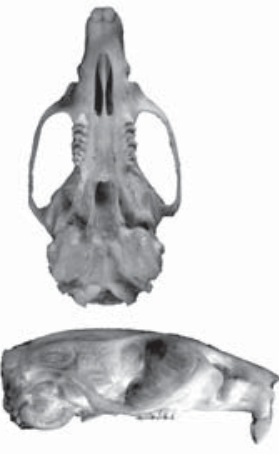

K

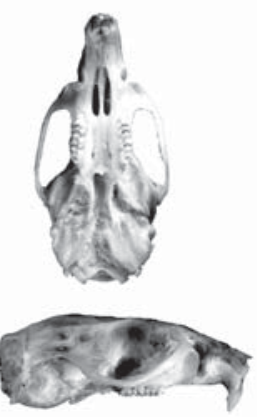

L

Figure 4. Skulls of adult Rattus from the Sunda Shelf (after Musser, 1986; Musser \& Califia, 1982; Musser \& Newcomb, 1985) and Southern Vietnam (original photo): $\grave{A}-R$. argentiventer (AMNH 107543, Bali Island); B $-R$. sikkimensis/R. andamanensis (USNM 533456, Thailand); C - R. diardi (AMNH 250104, Java); D - R.diardi (USNM 292689, Gunung Kinabalu, Sabah); E - R. tiomanicus roquei (AMNH 250114, Java); F $-R$. tiomanicus sabae (USNM 292789); G $-R$. tiomanicus (USNM 292672, Sabah); H - R. argentiventer, R6 (VL35, Vinh Long); I $-R$. andamanensis, R7 (BZM1, Bu Gia Map); J - R. tiomanicus, R3 (Lo37, Lo Go Xa Mat); K — R. tiomanicus, R3 (VL26, Vinh Long); L — R. tiomanicus, R3 (SM1, Xuyen Moc). 
ter (Musser \& Newcomb, 1983; Corbet \& Hill, 1992). Thus, we can confirm a correct taxonomic name for this haplogroup and approved the distribution of the species well to the north from the earliest presumed natural area (Malay Peninsula southward of the Isthmus of Kra), at least as far as the Mekong delta.

Comparison of craniometrical peculiarities of our original specimens with descriptions of morphology and images of skulls presented in the literature (Fig. 4) allowed us to attribute haplogroup R7 to Rattus sikkimensis, currently synonymized with $R$. andamanensis. The skull structure of these forms is very similar (Fig. 4B, I). The coarse structure of the skull with profound angular shelves and ridges, very spectacular shaped, well-elongated, narrow and tapering into extremities incisive foramina, and especially small, low and visually appreciable angular bulla (which is most spectacular on side view), are all characters composing distinctive features of the species. The rat is an entirely wild (nonsynanthropic) species that has been caught in Nam Cat Tien National Park and Bu Gia Map Nature Reserve in matured non- or lightly-disturbed dipterocarp forests. It is exactly the same genetic lineage listed for Western Thailand reported by Pages et al. (2010). That is fairly large rat with a chestnut-colored or dull brown upper part and a fairly coarse coat, bearing long dark brown or black guard hairs along the back, which penetrate the main hair coat and project more than $1 \mathrm{~cm}$ beyond. In Nam Cat Tien, the species has a perceptible yellowish hue or even obvious yellow belly with fairly well demarcated borders between the coloration of upper and lower parts of body, whereas specimens from Bu Gia Map are more consistent with descriptions of the morphae koratensis/remotus in Corbet \& Hill (1992) in their appearance and have a dirty-whitish or creamy abdomen. The hind feet are broad, and the dorsal sides are also uniformly yellowish, ochreous-colored or bear a broad grayish band. In contrast to the most other Rattus species, the tail is covered to the very tip by short tough brownish hairs, with the dorsal side colored appreciably lighter, with a visible limit of colors transition. Thus, we have to agree again with the accuracy of the taxonomic species name for haplogroup R7 as corresponding to $R$. andamanensis and approve distribution of the species to East Indochina. It is worth emphasizing that the species is very similar in its general appearance with many of the insular morphae of Rattus traditionally treated as $R$. diardi (Fig. 4C, D) and now treated as $R$. rattus, $R$. tiomanicus or $R$. tanezumi. However, there is still not any available genetic data for haplogroup R7 from anywhere beyond continental Indochina. The fact that the species was described from the Andaman Islands allows us to assume its distribution (or the existence of any sister or sibling species) in the Sunda Shelf islands. If this species is actually inhabits these locations, the taxonomical name diardi may be applied to them. However, R. andamanensis comprises an independent clade in the genus that is genetically well-segregated from species of the rattus group
(R.rattus, R, tanezumi, R. losea, R. tiomanicus; haplogroups R1-R4 and $R$. hoffmanni), so it is hardly if any correct to place it among this group of species.

However, the conclusions drawn above vary from and even contradict with the conclusions of Robins et al. $(2007,2010)$ and Pages et al. (2010) in whether the name diardi should be attributed to haplogroups R3. By comparing external appearance (white belly, sleek, soft and silky hair coat, a tail much longer than body length) and skull structure (Fig. $4 \mathrm{I}-\mathrm{G}$ and $\mathrm{J}-\mathrm{L}$ ) where an appreciably larger bulla can be seen, oblong shaped rostrum, much less pronounced bone ridges, slender, even fragile zygomatic arches, more long and broad row of molars. It can be clearly recognized that the species inhabiting south of Vietnam, Thailand and Cambodia and bearing haplotype R3 is a member of the rattus group but certainly not diardi, the morph to which rats having a appreciably different appearance (much larger and generally darker colored with coarse hair coat and invariably darker, brownish-yellow, buff or dark gray abdomen) have generally been attributed.

As shown in Fig. 3, the haplogroup R3 is independent, high-supported clade and cannot be ascribed to any other species of the rattus group, $R$. rattus (R1), $R$. tanezumi (R2) or $R$. losea (R4). The external appearance, skull structure and especially their natural area (wide distribution of the haplogroup R3 on many Sunda Archipelago islands, to Java and even Sulawesi) permit us to assume the attribution of the morph to R. tiomanicus. It is exactly this rat species from the rattus group (smaller in size, with white belly and sleek and silky hair coat, sometimes erroneously identified and treated under the name $R$. tanezumi) for which this name was earlier being used (Musser \& Califia, 1982; Musser \& Newcomb, 1985; Musser, 1986; Corbet \& Hill, 1992; Musser \& Carleton, 2005). Thus, the facts allow us to assume that the most abundant and most widely distributed species of the rattus group in Southern Vietnam is the species also distributed throughout most of Thailand, Cambodia, the Malay Peninsula, the islands of Java and Sulawesi and even Sri Lanka (Pages et al., 2010; Robins et al., 2007, 2010). The taxon should be named as $R$. tiomanicus.

This species has some distinctive features in their external morphology that can help separate it from conjointly distributed $R$. argentiventer or $R$. tanezumi. To distinguish it from the former, it has a clear white belly and dull, brownish, rather than reddish, coloration of its backside and a light grayish strip instead of homogenous gray coloration on the dorsal side of the feet. In contrast to some individuals of $R$. tanezumi, which also have a white abdomen, $R$. tiomanicus bears a widely-spread rather than closely-approximating caudal pair of mammilla and perceptible (especially for adult males) long guard hair coming out of the main coat nearly $1 \mathrm{~cm}$. The last feature is often noted as the distinctive character for $R$. remotus $/ R$. andamanensis (Marshall, 1977), but the latter is completely wild forest species having a distinctly different hair coat tex- 
ture, tail downiness, belly coloration and a specific skull compared to any species of rattus group.

If haplogroup R3 may be attributed to R. tiomanicus, the question still exists on a proper taxonomic name for haplogroup R5, which inhabits both Peninsular Thailand (Pages et al., 2010), and Jakarta and the Cibodas Forests in Java, Indonesia (Robins et al., 2007). Unfortunately, these authors did not discuss the external appearance, so nothing is known on the morphological peculiarities of this rats. We failed to find any haplotypes of the R5 group in Vietnam and cannot reasonably speculate about their taxonomical attribution. However, it may well be Rattus anandalei Bonhote, 1903 can be used as one of possible name for it which is known to inhabit the Malay Peninsula, Singapore and neighboring islands (Musser \& Newcomb, 1983). The species is also supposed to belong to the rattus group but shows some specific characters in their morphology preventing it to be drawn in with any other morphae from this study.

It is also worth to note that the fact the $R$. tiomanicus inhabiting continental Indochina may well pose a question about privilege of this taxonomic name as the oldest and hence general synonym. The species $R$. germani Milne-Edwards, 1872 was described from Con Son Island (Con Dao Archipelago, Southern Vietnam) and has priority over R. tiomanicus Miller, 1900 from Tioman Island (Malaysia). However, we found that the Con Son Island is actually inhabited by representatives of two haplogroups/species, R2 R. tanezumi and R3 $R$. tiomanicus (Tab. 1). With this fact being the case and bearing in mind that the initial description was not explicit and lacking the type material, it is hardly possible to argue which of these species the description actually mentioned.

Finally, we would like to express a desire that subsequent papers on the phylogeny and phylogeography of the genus Rattus be based on the established numeration of phylogenetic groups following Robins et al. (2007) and Pages et al. (2010) with our amendment: R1 (R. rattus, Euro-Oceanian type), R2 (R. tanezumi, Oriental type), R3 (R. tiomanicus, Sundaic type), R4, $(R$. losea), R5 (perhaps $R$. anandalei, needs more precision), R6 ( $R$. argentiventer), R7 ( $R$. andamanensis), R8 (R. exulans), R9 (R. norvegicus) and R10 (R. nitidus). The numeration may be developed and extended by applying indexes for newly discovered genetic lineages. The system of nomination allows more certainty in established taxonomy for a feature and finally attaining full comparability of the data obtained by independent researchers.

ACKNOWLEDGEMENTS. This study was supported by and performed at the Joint Vietnam-Russian Tropical Research and Technological Centre, South Division, Ho Chi Minh City, Vietnam. We would like to thank the Dr. V.V. Suntsov, Dr. N.I. Suntsova, D.A. Makarov and A.V. Schinov (Severtsov Institute of Ecology and Evolution, Russian Academy of Sciences, Moscow, Russia), Dr. A.V. Abramov (Zoological Institute, Russian Academy of Sciences, Saint-Pe- tersburg, Russia), and Dr. S.V. Kruskop (Zoological Museum of Moscow State University, Moscow, Russia), who supplied us with a significant part of material. We thank also Dr. Le Nhi (Institute of Pasteur, Ho Chi Minh City, Vietnam) and the administration of Nam Cat Tien, Hoang Lien, and Con Dao National Parks, Binh Chau, Ngoc Linh, Vinh Cuu (Ma Da) and Bu Gia Map Nature Reserves for administrative help in managing our research. We also warmly thank the Deputy Director of Science at Nam Khoa Biotech Inc. (Ho Chi Minh City, Vietnam) Dr. Pham Hung Van for technical support in sequencing procedures.

\section{References}

Baker R.J. \& Bradley R.D. 2006. Speciation in mammals and the genetic species concept // Journal of Mammalogy. Vol.87. P.643-662.

Bastos A.D., Nair D., Taylor P.J., Brettschneider H., Kirsten F., Mostert E., von Maltitz E., Lamb J.M., van Hooft P., Belmain S.R., Contrafatto G., Downs S. \& Chimimba C.T. 2011. Genetic monitoring detects an overlooked cryptic species and reveals the diversity and distribution of three invasive Rattus congeners in South Africa // BMC Genetics. Vol.12. P.26.

Bradley R.D. \& Baker R.J. 2001. A test of the genetic species concept: cytochrome $b$ sequences and mammals // Journal of Mammalogy. Vol.82. P.960-973.

Chinen A.A., Suzuki H., Aplin K.P., Tsuchiya K. \& Suzuki S. 2005. Preliminary genetic characterization of two lineages of black rats (Rattus rattus sensu lato) in Japan, with evidence for introgression at several localities // Genes and Genetic Systems. Vol.80. P.367-375.

Corbet G.B. \& Hill J.E. 1992. The Mammals of the IndoMalayan Region: A Systematic Review. Oxford: Oxford University Press. 488 p.

Ellerman J.R. 1949. The Families and Genera of Living Rodents. London: British Museum (Natural History). Vol.3. Pt.1. 210 p.

Ellerman J.R. \& Morrison-Scott T.C.S. 1966. Checklist of Palaearctic and Indian Mammals, 1758 to 1946. Second edition. London: British Museum of Natural History. $810 \mathrm{p}$.

Hall T.A. 1999. BioEdit: a user-friendly biological sequence alignment editor and analysis program for Windows 95/ 98/NT // Nuclear Acids Symposium. Ser.41. P.95-98.

Irwin D., Kocher T.D. \& Wilson A.S. 1991. Evolution of the cytochrome $b$ gene of mammals // Journal of Molecular Evolution. Vol.32. P.128-144.

Jones J.K., Jr. \& Johnson D.H. 1965. Synopsis of the lagomorphs and rodents of Korea // University of Kansas Publications, Museum of Natural History. No.16. P.357407.

Kocher T.D., Thomas W.K., Meyer A., Edwards S.V., Pääbo S., Villablanca F. \& Wilson A. 1989. Dynamics of mitochondrial DNA evolution in animals: amplification and sequencing with conserved primers // Proceedings of National Academy of Sciences of USA. Vol.86. P.61966200 .

Kumar S., Tamura K. \& Nei M. 2004. MEGA3: Integrated software for molecular evolutionary genetics analysis and sequence alignment // Briefings in Bioinformatics. Vol.5. P.150-163. 
Kuznetsov G.V. 2006. [Mammals of Vietnam]. Moskva: KMK Scientific Press Ltd. 420 p. [in Russian].

Lunde D.P. \& Nguyen Truong Son. 2001. An Identification Guide to the Rodents of Vietnam. New York: Center for Biodiversity and Conservation, American Museum of Natural History. 80 p.

Marshall J. 1977. A synopsis of the Asian species of Mus // Bulletin of American Museum (Natural History). Vol.158. P.173-220.

Musser G.G. 1986. Sundaic Rattus: definitions of Rattus baluensis and Rattus korinchi // American Museum Novitates. No.2862. P.1-24.

Musser G. \& Califia D. 1982. Results of the Archbold expeditions. No.106. Identities of rats from Pulau Maratua and other islands of East Borneo // American Museum Novitates. No.2726. P.1-30.

Musser G.G. \& Carleton M.D. 1993. Family Muridae // Wilson D.E. \& Reeder D.M. (eds.). Mammal Species of the World. A Taxonomic and Geographic Reference. Second edition. Washington: Smithsonian Institution Press. P.501-755.

Musser G.G. \& Carleton M.D. 2005. Superfamily Muroidea // Wilson D.E. \& Reeder D.M. (eds.). Mammals Species of the World. A Taxonomic and Geographic Reference. Third edition. Baltimore: Johns Hopkins University Press. Vol.2. P.894-1531.

Musser G.G. \& Newcomb C. 1983. Malaysian murids and the giant rat of Sumatra // Bulletin of American Museum (Natural History). Vol.174. P.327-598

Musser G.G. \& Newcomb C. 1985. Definition of Indochinese Rattus losea and a new species from Vietnam // American Museum Novitates. No.2814. P.1-32.

Nowak R.M. 1999. Walker's Mammals of the World. Sixth edition. Baltimore and London: The Johns Hopkins University Press. Vol.2. P.837-1936.

Pages M., Chaval Y., Herberteau V., Waengsothorn S., Cosson J.-F., Hugot J.-P., Morand S. \& Michaux J. 2010. Revisiting the taxonomy of the Rattini tribe: a phylogeny based delimitation of species boundaries // BMC Evolutionary Biology. Vol.10. P.184.

Pavlinov I.Ya. 2005. [Systematic of Recent Mammals]. Second edition. Moskva: Izdatel'stvo Moskovskogo Universiteta. 297 p. [in Russian].

Robins J.H., Hingston M., Matisoo-Smith E. \& Ross H.A. 2007. Identifying Rattus species using mitochondrial DNA // Molecular Ecology Notes. Vol.7. P.717-729.
Robins J.H., McLenachan P.A., Phillips M.J., McComish B.J., Matisoo-Smith E. \& Ross H.A. 2010. Evolutionary relationships and divergence times among the native rats of Australia // BMC Evolutionary Biology. Vol.10. P.375.

Ross H.A, Lento G.M., Dalebout M.L., Goode M., Ewing G., McLaren P., Rodrogo A.G., Lavery S. \& Baker C.S. 2003. DNA surveillance: web-based molecular identification of whales, dolphins, and porpoises // Journal of Heredity. Vol.94. P.111-114.

Sambrook J., Fritsch E.F. \& Maniatis T. 1989. Molecular Cloning: A Laboratory Manual. Cold Spring Harbor: Cold Spring Harbor Lab. 256 p.

Savolainen V., Cowan R.S., Vogler A.P., Roderick G.K. \& Lane R. 2005. Towards writing the encyclopedia of life: an introduction to DNA barcoding // Philosophical Transactions of the Royal Society of London. Series B. Biological Sciences. Vol.360. P.1805-1811.

Schlick N.E., Jensen-Seaman M.I., Orlebeke K., Kwitek A.E., Jacob H.J. \& Lazar J. 2006. Sequence analysis of the complete mitochondrial DNA in 10 commonly used inbred rat strains // American Journal of Physiology and Cell Physiology. Vol.291. P.1183-1192.

Suzuki H., Tsuchiya K. \& Takezaki N. 2000. A molecular phylogenetic framework for the Ryukyu endemic rodents Tokudaia osimensis and Diplothrix legata // Molecular Phylogenetic and Evolution. Vol.15. P.15-24.

Suzuki H., Sato J.J., Tsuchiya K., Luo J., Zhang Y.-P., Wang Y.-X. \& Jiang X.-L. 2003. Molecular phylogeny of wood mice (Apodemus, Muridae) in East Asia // Biological Journal of Linnaean Society. Vol.80. P.469-481.

Tollenaere C., Brouat C., Duplantier J.-M., Rahalison L., Rahelinirina S., Pascal M., Mone H., Mouahid G., Leirs H. \& Cosson J.-F. 2010. Phylogeography of the introduced species Rattus rattus in the western Indian Ocean, with special emphasis on the colonization history of Madagascar // Journal of Biogeography. Vol.37. P.398410.

Truong T.T., Yoshimatsu K., Araki K., Lee B.H., Nakamura I., Endo R., Shimizu K., Yasuda S.P., Koma T., Taruishi M., Okumura M., Truong U.N. \& Arikawa J. 2009. Molecular epidemiological and serological studies of hantavirus infection in northern Vietnam // Journal of Veterinary and Medical Sciences. Vol.71 P.1357-1363.

Van Peenen P.F.D. 1969. Preliminary Identification Manual for Mammals of South Vietnam. Washington: US National Museum, Smithsonian Institution. 193 p. 